\title{
Kernos
}

Revue internationale et pluridisciplinaire de religion grecque antique

$23 \mid 2010$

Varia

\section{Porphyry, Sacrifice, and the Orderly Cosmos}

On the Philosophy to be Derived from Oracles Fr. 314 and 315

\section{Sarah Iles Johnston}

\section{Q OpenEdition \\ 1 Journals}

\section{Electronic version}

URL: http://journals.openedition.org/kernos/1571

DOI: 10.4000/kernos. 1571

ISSN: 2034-7871

\section{Publisher}

Centre international d'étude de la religion grecque antique

\section{Printed version}

Date of publication: 1 January 2010

Number of pages: 115-132

ISSN: 0776-3824

\section{Electronic reference}

Sarah Iles Johnston, «Porphyry, Sacrifice, and the Orderly Cosmos », Kernos [Online], 23 | 2010, Online since 10 October 2013, connection on 06 May 2019. URL : http://journals.openedition.org/ kernos/1571 ; DOI : 10.4000/kernos.1571 


\title{
Porphyry, Sacrifice, and the Orderly Cosmos:
}

\author{
On the Philosophy to be Derived from Oracles Fr. 314 and $315^{*}$
}

\begin{abstract}
Porphyry's statement from On the Cave of the Nymphs, in which he divides gods and their places of sacrifice into three groups, is familiar to scholars interested in how the Greeks may have categorized the divine world and its workings. But we have overlooked other important statements on these topics that Porphyry made in On the Philosophy from Oracles. Here I focus on fr. 314 and 315, where Porphyry quotes extensive portions of oracles in which Apollo divides the gods and their proper sacrifices into groups; Porphyry himself then streamlines and justifies those divisions. Although Apollo presents us with many more categories than we are accustomed to look for, his approach suggests that the drive to categorize was more common in ancient thought than recent scholarship has allowed. I also show that Porphyry works to collapse Apollo's categories into only three. I end with comments about how these observations may help us better understand our practices as scholars of religion.

Résumé : Dans L'Antre des Nymphes, Porphyre répartit en trois groupes les dieux et les lieux des sacrifices qui leur sont offerts. Une telle division est connue des chercheurs qui s'intéressent à la manière dont les Grecs pourraient avoir organisé le monde divin et ses interventions. Mais on a méconnu d'autres affirmations que Porphyre produit à ce sujet dans le traité Sur la philosophie tirée des oracles. Dans les fr. 314 et 315, Porphyre cite de longs extraits d'oracles dans lesquels Apollon répartit les dieux et leurs sacrifices en trois groupes. Il restructure lui-même et justifie ces divisions. Même si Apollon propose plus de catégories que celles auxquelles nous sommes habitués, son approche suggère que la tendance à la catégorisation était plus commune dans la pensée des Anciens que ne l'a prétendu la recherche récente. On voit aussi que Porphyre fait en sorte de ramener les catégories d'Apollon à trois seulement. En conclusion, de telles observations peuvent nous aider à mieux saisir nos pratiques en tant qu'historiens des religions.
\end{abstract}

Much ink has been spilt during the past few decades over the questions of whether we can properly speak of 'Olympian' versus 'chthonian' sacrifices and 'Olympian' versus 'chthonian' gods, or whether other dichotomizing alternatives such as 'sacrificing as to a god,' versus 'sacrificing as to a hero' better

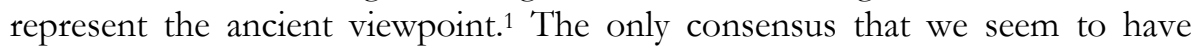

* An earlier draft of this work was presented at a conference on ancient sacrifice organized by Zsuzsana Varhélyi and Jennifer Kunst at Boston University in November of 2008; I thank the audience there for their helpful comments. I thank Fritz Graf for his comments on a later draft.

1 Particularly important studies are EKROTH (2002), esp. p. 245-251, and (1999); HENRICHS (1999); Nock (1944); PARKer (2005); Pirenne-Delforge (2008), p. 181-201 and 221-241; SCHLESIER (1991/92); SCULLION (2009), (2005) and (1994). My ideas in the latter part of the 
reached after all of this debate is that there can be no consensus: we have become acutely aware that ancient ways of speaking about different kinds of entities and different modes of worshipping them varied from period to period, from genre to genre, from author to author and probably even from occasion to occasion. It also seems clear now that the remarkable flexibility that characterized ancient systems of classification imbued them with remarkable powers of expression: the details of an ancient sacrifice helped to define the god or other entity to whom it was being offered and what was expected from him or her in the situation at hand. To the degree that distinctions between such concepts as what modern scholarship calls 'Olympian' and 'chthonian' ever existed in the ancient mind, they were moving targets, called in and out of existence as circumstances demanded, rather than rigidly defining two wholly different religious systems, divisions within a religious system, or entities within such systems.

In the course of these discussions, most of the ancient passages central to the debate have been repeatedly analyzed: the intentions of their authors, the nature of the works in which they are embedded and other issues of context have been thoroughly considered. One ancient passage that was considered central to the debate from its beginning, however, has remained almost untouched in recent decades. In his treatise On the Cave of the Nymphs in the Odyssey (hereafter, The Cave), Porphyry says (\$ 6):

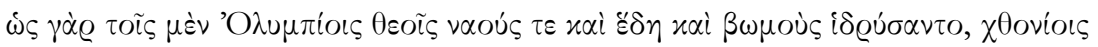

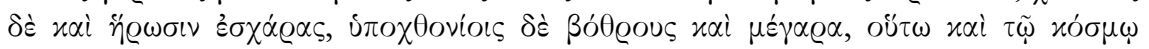

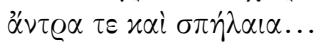

Just as they consecrated to the Olympian gods temples, shrines and altars; to the chthonioi and the heroes, sacrificial hearths; and to the bypochthonioi, ritual pits or trenches; so they dedicated caves and grottos to the cosmos...

One implication of the scholarly silence would seem to be that, because this passage is 'late', it is irrelevant to our understanding of Greek ritual as it was practiced on the ground in earlier periods. Jean Rudhardt came close to making this explicit (with Porphyry's text in mind): 'Les auteurs tardifs cherchent des correspondances entre les deux diversités, assignant par exemple un type défini de victimes à certains dieux, mais les documents classiques ne confirment pas leurs théories.'2

Although I understand the reasons for this evaluation - certainly, Porphyry's statements cannot be straightforwardly applied towards understanding religion in earlier periods - I nonetheless suggest that there are at least two reasons that we should take a closer look. First, it is bad practice to dismiss evidence solely

current essay were especially helped by the historically contextualized insights of SCHLESIER (1991/92). FAIRBANKS (1900) offered a remarkably early caution against a strict dichotomy.

2 RUdHARDT (1958), p. 251. 
because it is 'late'. It is true that some authors of later antiquity sought to bring a tidiness to religion that looks artificial to us, but we must remember that such authors dared not misrepresent the nature of the evidence with which they dealt too severely - and it must also be remembered that such evidence was far more abundantly available to them than it is to us. If we wish to lay to rest, once and for all, a dichotomizing approach to Greek religion, then we need to better understand what was meant by Porphyry - allegedly one of the strongest ancient spokesmen for such an approach. In other words, we must contextualize Porphyry's remarks on sacrifice as carefully as we have contextualized those of Plato or the tragedians.

Second, Porphyry's thoughts on such matters should be of intrinsic interest to us, aside from any light that they may, or may not, shed on earlier religious practices. This is not only because they help to illuminate religion in later antiquity per se, but also because Porphyry, like several other neoplatonists of approximately his time, was a prototype of what we now would call a historian of religion, insofar as he sought to understand why people performed certain rituals - what was their origin? How could they be justified? I have more than once been surprised at the way in which unraveling the structure of thought behind the neoplatonic interpretations of a religious practice lays bare the presumptions that modern scholars carry into their analysis. ${ }^{3}$ In short, it is possible that by better understanding Porphyry's approach to categorizing gods and the sacrifices appropriate to them, we may better understand our own approaches, and those of our modern predecessors.

A complete study of Porphyry's conception(s) of sacrifice is beyond the scope of a single essay, however - most obviously, any thorough discussion would have to take into account his lengthy treatise De abstinentia. ${ }^{4}$ What I will do here, instead, is to analyze some particularly pertinent fragments from his treatise On the Philosophy to be Derived from Oracles (hereafter, referred to in this essay as The Philosophy). ${ }^{5}$ Like so much else from that work, they have been almost completely overlooked by scholars, ${ }^{6}$ but as we will see, they offer a detailed parallel for Porphyry's comments in The Cave, and they demonstrate, as

\footnotetext{
${ }^{3}$ For example, JOHNSTON 2008a.

${ }^{4}$ Already Eusebius realized the complexity of Porphyry's views on sacrifice as articulated in his various works - although Eusebius chose to understand that complexity as a matter of internal contradiction, and therefore weakness. (He mentions the contradictions several times throughout his discussion of fr. 314 and 315 at PE IV, 8-10.)

5 The fragments first were collected within the study by WOLFF (1856) but were more recently edited as part of Andrew Smith's 1993 Teubner edition of all of Porphyry's fragments it is Smith's on texts that I base the translations I offer here.

${ }^{6}$ RUDHARDT (1958) noted them in passing in a footnote to his observations about the passage from The Cave on p. 251. EITREM (1948) briefly takes up the question of how Apollo intends his gods to be classified (more on this below). NOCK (1944) mentions a few lines of fr. 314 on p. 151-152, but does not analyze either it or fr. 315 as a whole.
} 
well, that the structure he built there was not completely his own invention. This will mark at least the beginning of a better contextualization of the famous remark in The Cave.

Luckily, we have a fairly good idea of what The Philosophy as a whole set out to do because the first part of it is preserved by Eusebius, who also preserves the fragments on which we will focus below. Eusebius says (fr. 303 Smith = Eus. PE IV , 6, 2-7, 2):

[Porphyry] seems to us to be familiar with demons and those that he calls gods, and to be their ambassador and to have investigated their affairs most exactly. Thus, in the book he called On the Pbilosophy to be Derived from Oracles, he made a collection of Apollo's oracles and the oracles of the other gods and the good daimones, choosing particularly those that he thought offered proof of the virtue of the oracles' discourses on the gods and as a petition on behalf of that art that he calls theosophy. ... First let us observe, however, how Porphyry swears, at the beginning of his work, to be speaking the truth:

(and here Eusebius begins to quote Porphyry himself):

Sure and steady is he who draws his hope of salvation from the only sure thing, and to such people you will impart [wisdom] without stinting. .... The present collection will contain a record of many doctrines of philosophy, as the gods prophesied them truly. ... And this collection will especially be useful for those who, having been burdened with the truth, prayed that encountering an epiphany from the gods, they would gain relief from their perplexity by the faithful teaching of those speaking [the oracles].

That Porphyry means specifically to address other people like himself - that is, those who wish to delve into divine matters - is made clear by another fragment from The Philosophy quoted almost immediately afterward by Eusebius (fr. 304 Smith = Eus. PE IV.7.2-8.1). Again addressing his readers, Porphyry says:

do not attempt to publish these things, nor cast them before the profane for the sake of your reputation or for the sake of gain or for the sake of any other unholy flattery. This would be dangerous not for you alone because you transgressed the [god's] commands, but also for me who trusted too easily someone to keep them to himself, who was not able to do so. They must be given to those who direct their lives to the salvation of the soul ( $\left.\psi \times x \tilde{\eta} \varsigma \sigma \omega \tau \eta{ }^{\prime}(\alpha)\right)$.

In sum, then, The Philosophy addresses an audience that already has faith in the idea that Apollo and other gods impart theological truths through oracles, but that also understands exegesis of those oracles to be necessary if they are to be put to their proper purposes. We should expect, therefore, that Porphyry's interpretations of the oracles are often apt to be sui generis, but that they nonetheless engage closely with what the oracle actually says. 
The fragments from The Philosophy that are most important for my present purposes are numbered 314 and 315 in Smith's collection (= Eus. PE IV; 8, 4 9, 7). In fr. 314, Porphyry says:

Following after what has been said concerning piety we shall record the responses given by [the gods] concerning their worship, part of which in anticipation we have set forth in the statements concerning piety. Here is an oracle of Apollo

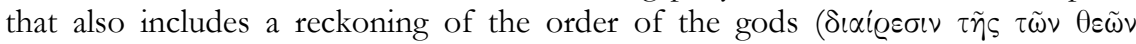

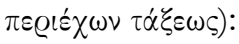

Friend who has entered on this heaven-tanght path, perform your sacrifices and do not forget the blessed gods, slaying your sacrifices now to the gods upon the earth (epichthonioi), now again to the gods of heaven (ouranioi); sometimes to the kings of the aither themselves and to those of the watery aer, and to [the kings of] of the seas and all those who dwell beneath the earth (hypochthonioi). For everything is bound up in the fullness of their nature.

I shall sing to you of how it is proper to perform the burnt offerings (kathagismous) of living creatures (be sure to write my oracle down on tablets): offerings to the gods upon the earth (epichthonioi) and to the gods of the beavens (ouranioi).

- Bright [victims] are for the gods of heaven (ouranioi); for the gods of the earth (chthonioi) use [victims] similar [to them] in color. Divide the sacrifices for the gods of the earth into three parts when you slay them.

- Bury the victims for the infernal gods (nerterioi) and pour the blood into a pit.

- For the nymphs, pour out honey and the gift of Dionysus.

- For those gods who fly around the earth constantly, having filled the flaming altar altogether with the blood of the victim, throw into the fire the body of a winged creature, sacrificing it.

- Then, having mixed honey with Deo's grain, place [the mixture in the fire] and throw in as well the aroma of frankincense and sprinkle on the barley grains.

- But when you look upon the sandy shore, pouring out grey sea water, offer the victim's head as a sacrifice and cast the rest of the animal, undivided, into the waves of the sea.

- Then, having done all of these things, make your way to the great company of the gods who live in the heavens (ouranioi) and those who live in the aer.

- Finally, for all the gods who dwell in the stars (astraioi) and those who dwell in the aither, let blood in fullest stream flow from the throat over the sacrifice. Make a banquet for the gods out of the limbs, giving the extremities to Hephaestus.

- The rest you can eat, filling the liquid aer with sweet aromas. When everything is done, send forth your prayers.

One might wish that, if Apollo was intending to give instructions, he had spoken in a more straightforward fashion; it is somewhat hard to keep track of all the different types of gods he mentions here, especially because he uses the poetic language typical of hexameter oracles. ${ }^{7}$ But one thing at least is clear: this oracle

7 That Apollo's words are confusing is noted as well by EITREM (1944) and WOLFF (1856) in some of the footnotes he appends to his edition of the fragments on p. 112-121. Fritz Graf, commenting on an earlier draft of this essay, developed a means of organizing Apollo's recommendations that first broke the gods into four groups - epichthonioi, ouranioi (with subdivisions 'gods of the aer' and 'gods of the aither'), thalassioi and hypochthonioi. (He omitted the nymphs for purposes of 
attempts to prescribe what kind of sacrifice each of many types of gods should receive. In doing so, it goes beyond other, somewhat similar oracles of Apollo that date to approximately the same time, which advocate making specific sacrifices to specific gods to address specific problems - for example, one of several Clarian oracles that are connected with the plague that swept through the area in the second century orders the people of Pergamon to sacrifice a two-year-old heifer to Athena, a three-year-old bullock to Zeus and Zeus Bacchios, and a bull to Asclepius if they wish to stop a plague. ${ }^{8}$ In fr. 314 , in contrast, Apollo seems to be offering broader guidelines that would be applicable in many circumstances.

Incidentally, the questions of what the 'real' source of such oracles is, and how such oracles were generated (at an institutional oracle or during a private séance of some kind), are very difficult to resolve. Aude Busine ${ }^{9}$ has suggested that the oracle in fr. 314 came from Claros, but it seems impossible to prove this either way; Porphyry's admonition, in fr. 304, to keep the oracles that he records safe from profane ears could be taken to suggest that they emerged during private séances somewhat similar to those that are imagined to have produced the Chaldean Oracles. In a sense, the distinction is irrelevant anyway, insofar as we know that, during later antiquity, the great institutional oracles entertained questions of theological complexity similar to those that we glimpse in the Chaldean Oracles and other esoteric literature and to which the fragments currently under discussion bear resemblance as well. In any case, whatever the earthly provenance of Apollo's words in fr. 314 may have been, they indicate an interest, on the part of one or more of his enquirers, in understanding the proper means of worshipping different types of gods. As far as I know, this is the first straightforward attestation of such an interest that we have. It is also the first straightforward statement that we have for an assumption that the gods could be divided into types in the first place, even if some of the earlier passages that scholars have discussed as part of the 'Olympian/chthonian' debate implicitly assume divisions.

Apollo uses titles for his types of gods that vary a bit. Most of them are adjectival: the ouranioi, the chthonioi, the bypochthonioi, and so on. Others comprise

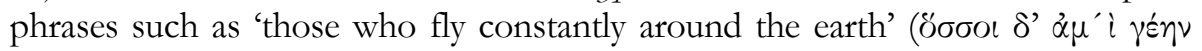

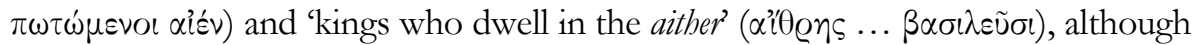
the latter sort of gods are also referred to by the adjective aitherioi. He also speaks

schematization.) Graf suggested that the sacrificial modes could be divided in half: white for ouranioi (including astraioi and aitherioi) and dark for all others. Graf's proposals are closely similar to various means of subdividing the gods and the modes of sacrifice with which I experimented while working on this essay. In the end, however (as I will discuss shortly below), I found it impossible to derive a system from Apollo's words that is free from internal contradictions or at least significant grey areas; this is because Apollo neither works from a pre-existing system nor takes as his primary aim the establishment of a system in any formal sense of that word.

8 Merkelbach and Stauber (1996) \# 2. See also Graf (1992) and VArhélyi (2001).

${ }^{9}$ Busine (2005), p. 35 and $c f$. p. 160-163. 
of nymphs, a term that is familiar from earlier sources, and he metaphorically uses the individual names of a few familiar gods: Dionysus, Deo (that is, Demeter) and Hephaestus. It is possible that Apollo uses some of his terms synonymically. For instance, perhaps the 'gods who fly constantly around the earth' are the same as the gods of the aer, given that both receive birds as holocaust offerings and given that ' $a e r$ ' usually refers to the realm just above the earth. It is also possible that either or both of these categories coincide with that of the epichthonioi, since that adjective can mean 'frequenting the earth' (Hesiod uses epichthonioi in this way when describing the daimones into which the mortals of the Golden Age were transformed after death - the daimones wander over the earth, watching what the living do and allotting rewards and punishments accordingly). ${ }^{10}$ But notably, Apollo bimself does not explicitly collapse any of the terms he uses into more inclusive categories or explain how all of these ranks fit together either operationally, in terms of the specific portions of the cosmos that they each inhabit, or in any other way. In spite of what Porphyry says when he introduces the fragment and again when he interprets it, then, in the final analysis

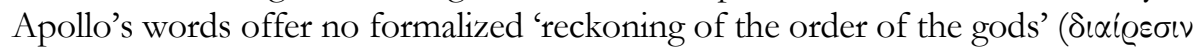
$\tau \tilde{\eta} \varsigma \tau \tilde{\omega} \nu \theta \varepsilon \tilde{\omega} \nu \pi \varepsilon \varrho \iota \dot{\varepsilon} \chi \omega \nu \tau \dot{\alpha} \xi \varepsilon \omega \varsigma)$. Apollo wishes to indicate how certain types of gods will be pleased by certain kinds of things, but he stops short of tidying everything in the divine world up into a neat, and complete, structure of mutually exclusive categories.

The task of tidying is undertaken by Porphyry instead, in a detailed analysis that comprises fr. 315 . The fragment reads:

This is the method of sacrifices, which are accomplished according to the reckoning of the gods that I mentioned earlier. For whereas there are gods beneath the earth (bypochthonioi), and upon the earth (epichthonioi), and those beneath the earth are [also] called infernal gods (nerterioi) and those upon the earth are also called gods of the earth (chthonioi) - for all of these in common [Apollo] commands the sacrifice of black four-footed victims. But with regard to the manner of the sacrifice he makes distinctions: for to the gods upon the earth (epichthonioi) he commands the victims to be slain upon altars, but to the gods beneath the earth (bypochthonioi) he commands the victims to be slain over pits, and moreover after the offering to bury the bodies therein.

That four-footed animals are appropriate to all these deities, the god himself added, when he was questioned,

Four-footed victims must be given only to gods of the earth (chthonioi) and gods beneath the earth (hypochthonioi). For gods of the earth (chthonioi) the new limbs of lambs [are appropriate].

But to the gods of the aer Apollo commands us to make holocaust offerings of winged creatures, letting the blood run round upon the altars; winged creatures are also [appropriate for] the gods of the sea, but they must be cast alive into the waves and must be black. For he says: 


\begin{tabular}{|c|c|c|c|}
\hline $\begin{array}{l}\text { चू } \\
\mathbb{E} \\
\tilde{\Xi}\end{array}$ & & 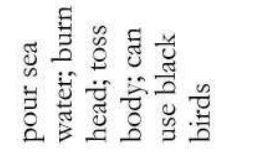 & 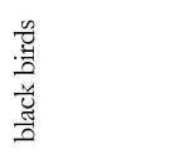 \\
\hline 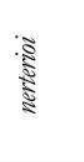 & \multirow{2}{*}{ 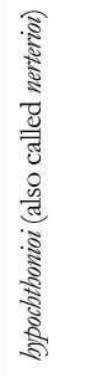 } & 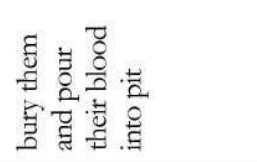 & 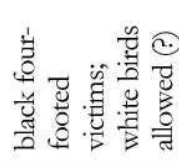 \\
\hline $\begin{array}{l}\text { हू } \\
\text { हू } \\
\text { हूँ }\end{array}$ & & 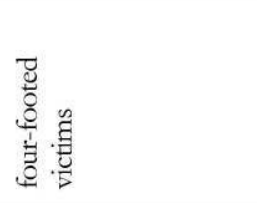 & 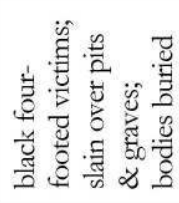 \\
\hline है & \multirow{2}{*}{ 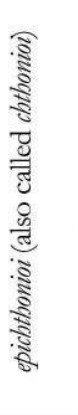 } & 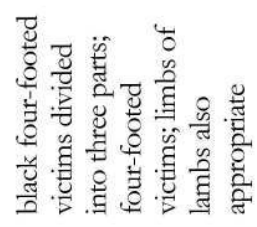 & 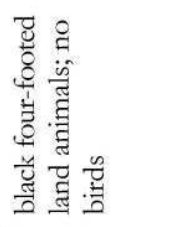 \\
\hline$\frac{\sqrt{2}}{5}$ & & & 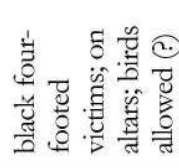 \\
\hline 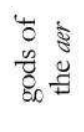 & & 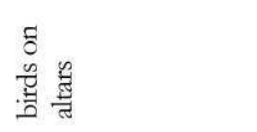 & 苞营产 \\
\hline 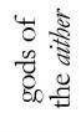 & \multirow{3}{*}{ 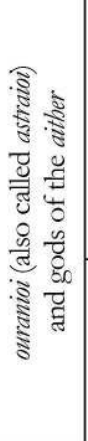 } & 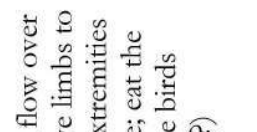 & \multirow{3}{*}{ 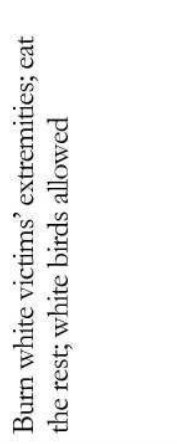 } \\
\hline है & & 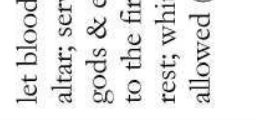 & \\
\hline s & & 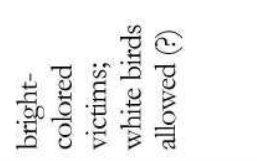 & \\
\hline 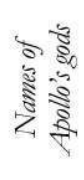 & 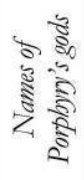 & 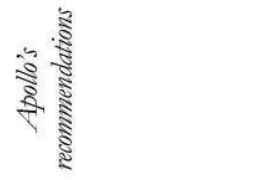 & 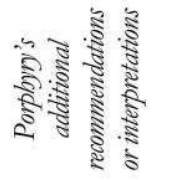 \\
\hline
\end{tabular}




\section{Winged creatures for the gods, but for the sea gods black.}

He names winged creatures for all of the gods except those of the earth (chthonioi), and he names black for the sea gods only, and therefore [he intends] white for the other gods. But to the gods of the heavens (ouranioi) and the gods of the aither he commands us to consecrate the extremities of white victims, and to eat the other parts: for these animals only are appropriate for eating, and not the others. But those whom in his classification he calls gods of heaven (ouranioi), here he calls gods of the stars (astraioi).

Will it then be necessary to explain the symbola of the sacrifices, clear as they are to those who are in-the-know? There are four-footed land animals for the gods of the earth (chthonioi) because like rejoices in like. And the sheep is of the earth (chthonios) and therefore dear to Demeter, and in heaven the ram, with the help of the sun, brings forth out of the earth its display of fruits. ${ }^{11}$ The ram must be black, for the earth is dark in nature. The victim must be divided into three parts because three is the symbol (symbolon) of the corporeal and earthy.

To the gods upon the earth (epichthonioi) one must make sacrifices high upon altars, for these gods dwell on earth; but to the gods beneath the earth (bypochthonioi) one must make sacrifices in a pit and in a grave, where they abide.

To the other gods we must offer birds, because all things are in swift motion. For the water of the sea is also in perpetual motion, and dark, and therefore victims of this kind are suitable.

But white victims are appropriate for the gods of the aer because the aer itself is filled with light, being of a translucent nature.

For the gods of heaven (ouranioi) and the gods of the aither, the parts of the animals that are lighter [in weight] are appropriate, and these are the extremities.

With these gods we must participate in the sacrifice; for they are the givers of good things, but the others are averters of evil.

I have summarized what Apollo and Porphyry tell us about the gods and their proper sacrifices in fr. 314 and 315 in the chart on the previous page. ${ }^{12}$

What are we to make of all of this? We might first observe that in fr. 315, Apollo himself can be understood to have only confused matters further than he already had in fr. 314. In fr. 314, Apollo says that the bypochthonioi and nerterioi must receive dark animals as sacrifices, but he then seems to contradict this in fr. 315 when he says that only the gods of the sea should receive dark-colored birds - and that all other gods (is this meant to include the bypochthonioi and nerterioi?) should receive white. Apollo advocates sacrificing four-footed victims only to the chthonioi and bypochthonioi, and yet he directs that the limbs of sacrifices be offered to the ouranioi and astraioi. I doubt that the word used for 'limbs' here - үuĩ - can be applied to birds' legs, so Apollo must mean mammals, that is, four-footed sacrificial victims, which implicitly contradicts his

11 Apollo seems to be referring to the constellation Aries here.

12 For the sake of simplicity, I have omitted from this chart the nymphs and the 'gods who fly around the earth constantly,' although I will return to them later in this essay. 
other statement. Of course, Porphyry may be taking Apollo's statements in fr. 315 from two or more different oracles; the sentence 'That four-footed animals are appropriate to all of these deities the god himself added, when he was questioned,' particularly suggests that for that part of his information, Porphyry was referring to a different oracle from that which he quoted in fr. $314 .{ }^{13}$

But if so, such an addition certainly worked against Porphyry's more obvious, and vigorous, attempts to bring order to Apollo's words overall. Most notably along these lines, Porphyry claims, at the beginning of fr. 315, that there are three groups of gods: he collapses the nerterioi into the bypocbthonioi, the chthonioi into the epichthonioi, and the astraioi into the ouranioi (further suggesting that the gods of the aither are part of this third group as well). It is interesting that he foregoes explicitly aligning either the gods of the sea or the gods of aer with one of these three main groups. This may be because he realized that such a move would bring him into trouble, given that neither type of god fits into any group straightforwardly. (One might hypothesize that the gods of the sea belong to the hypocbthonioi, based on what Apollo and Porphyry say about the dark color of their sacrifices, but such a categorization would strike an odd note, given the ways in which Poseidon, for example, had long been worshipped. The gods of the aer arguably could belong either to the ouranoi, judging from the fact that their sacrificial victims are white and that the aer itself is described as 'filled with light'; or to the epichthonioi, based on the fact that the aer is directly above the earth.) Porphyry also foregoes aligning the 'gods who fly around the earth constantly' and the nymphs with any of the three groups. I suggested above that the former were meant to be synonymous with either the gods of the aer or the epichthonioi, and one might guess that the latter would be classed among the epichthonioi, but for my purposes at the moment, such questions are irrelevant; the point is that Porphyry leaves them out of his systematization, apparently because he was working towards three clear, mutually exclusive categories.

That he did so will not surprise anyone who has studied philosophicallyinfluenced religious systems of later antiquity. In the works of Iamblichus, Proclus and other authors we encounter carefully delineated hierarchies of extra-human entities, in which each entity may be not only categorized and minutely described so as to be fully articulated from the others, but also assigned to a specific portion of a well-ordered cosmos. Each entity has its particular duties to perform and, according to Iamblichus, each one has its particular mode of manifesting itself, as well; in the second book of his treatise Concerning the Mysteries, Iamblichus gives detailed instructions as to how a human can recognize each type of entity, lest mistakes be made. In such systems, there is no room for overlap or confusion amongst types; we find

${ }^{13}$ So also, the sentence, 'But those whom in his classification he calls gods of heaven, bere be calls gods of the stars' suggests that Porphyry used more than one oracle as source material. 
none of the sloppiness - or to call it more positively the improvisational flexibility - that marks most working religious systems. It is revealing that Porphyry refers in the first line of his own interpretation (the first line of $\mathrm{fr}$. 315 , that is) to the 'reckoning of the gods that I mentioned earlier' ( $\tau \dot{\nu}$

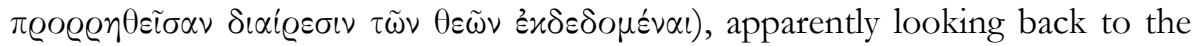
phrase with which he introduced fr. 314, where he claims that Apollo's words include a 'reckoning of the order of the gods.' The repetition marks the urgency of Porphyry's desire to find - or if necessary, impose - clarity and rules upon the oracles that he is recording. It is notable, too, that he ends up with three main, mutually exclusive categories. The tripartite is typical of neoplatonism: cosmologically, for example, the neoplatonists posited an ontological realm that centered on the sun, a realm that centered on the moon, and a realm that centered on the earth. When explaining the composition of a human being, they proposed that each included a portion of intellect, a portion of the corporeal and a portion of soul that mediated between the two others. And so forth - three was a very significant number in neoplatonism.

Towards the end of fr. 315, Porphyry tries to shore up the system that he is building by logic and by referring to symbola - that is, to the neoplatonic belief that each superhuman entity had ties to plants, animals, minerals and other objects in the material world, and that there were reasons behind the ties, which could be discerned if one were among the cognoscenti. Yet in spite of Porphyry's efforts, we again perceive some strain in his arguments: are the extremities of animals really lighter in weight than other parts of the body, save for the fact that they are smaller in size once they have been lopped off? Is the ram really dedicated to Demeter for astrological reasons? Is shared perpetual motion a good enough reason to associate birds with the sea? If we had fuller information about neoplatonic symbolic systems (or other ancient symbolic systems) we might discover that Porphyry's arguments are anchored in tradition, but even so, one comes away from this part of Porphyry's discussion with the impression that he is working rather hard to bring an order to the information he has received.

Let us summarize what we can say about fr. 314 and 315 so far:

(1) At some time prior to Porphyry's death in about $305 \mathrm{CE}$, someone recorded an oracle from Apollo that laid out some guidelines for sacrificing to different kinds of gods. Depending on how one interprets Apollo's possibly synonymic language, he was speaking of between six and eleven different types of gods. ${ }^{14}$ Apollo's means of describing the gods focused primarily on where in the cosmos they dwelt.

\footnotetext{
14 Six by the logic, for example, of the scheme sketched by Graf in note 8 above (if we include the nymphs), or arguably five, one of which has two subdivisions; eleven if we count each group mentioned by Apollo separately: epichthonioi, ouranioi, kings of the aither, kings of the aer, kings of the sea, bypochthonioi, chthonioi, nerterioi, nymphs, gods who fly around the earth constantly,
} 
(2) The distinctions that Apollo made amongst the gods' proper sacrifices focused on the color of animal (white or black); the number of parts into which the animal should be divided and what parts should be given to the gods; the means of disposal (burning, burial, etc.); and the type of animal (birds or 'fourfooted animals,' i.e., mammals). Several of these distinctions cross the boundaries that Apollo establishes amongst his different types of gods - that is, there is no one-to-one, mutually exclusive system that pairs types of gods with sacrificial characteristics. Different types of gods may receive offerings that share some characteristics with those of other gods.

(3) Porphyry tried to construct a more orderly system from Apollo's words. In particular, he reduced Apollo's many types of gods into three main categories: ouranioi, epichthonioi and bypochthonioi (although it is not always clear to which category he assigned each type of god).

(4) Porphyry strove to clarify and justify Apollo's sacrificial system, partially through logic and reference to the neoplatonic idea of symbola. This led him to explain why certain animals were chosen for each god, why they were sacrificed in certain places, etc.

The result of (3), of course, is a system of gods almost identical to that in the more famous passage from The Cave with which I started this essay:

\begin{tabular}{|c|c|c|c|}
\hline gods in The Cave & Olympians & chthonioi and heroes & bypocbthonioi \\
\hline gods in The Philos. & ouranioi $=$ astraioi & epichthonioi $=$ chthonioi & bypocbthonioi $=$ nerterioi \\
\hline
\end{tabular}

When we look at (4), however, we notice a difference:

\begin{tabular}{|c|c|c|c|}
\hline gods in The Cave & Olympians & chthonioi and heroes & bypochthonioi \\
\hline $\begin{array}{c}\text { where they receive } \\
\text { sacrifice in The Cave }\end{array}$ & $\begin{array}{c}\text { on altars at temples } \\
\text { and shrines }\end{array}$ & $\begin{array}{c}\text { at sacrificial hearths } \\
\text { (on the ground) }\end{array}$ & in pits and trenches \\
\hline gods in The Philos. & ouranioi = astraioi & epichthonioi $=$ chthonioi & bypochthonioi $=$ nerterioi \\
\hline $\begin{array}{c}\text { where they receive } \\
\text { sacrifice in The Philos. }\end{array}$ & \multicolumn{2}{|c|}{ on altars } & in pits and graves \\
\hline
\end{tabular}

The tripartite division of sacrificial places that neatly corresponds to the tripartite division of gods in The Cave becomes a bipartite division in The Philosophy. It is easy to guess why - epichthonioi are twice contrasted with ouranioi in

astraioi (I give them here in the order in which they appear in fr. 314). The latter assumption is unlikely - it is probable that some of Apollo's terms are synonyms for one another - but as I have tried to demonstrate, if it is impossible to be sure which can be safely collapsed into which. More to the point, the impossibility underscores the lack of intention, on Apollo's part, of providing an air-tight structure. 
the first lines of Apollo's words in fr. 314, thus necessitating Porphyry's equation of them with chthonioi if he wished to collapse Apollo's many types of gods into three categories, but Porphyry could not contradict Apollo's dictate that the epichthonioi be given sacrifices at altars, which appears at the beginning of fr. 315 . Nothing makes it clearer than this situation how deeply invested Porphyry was in creating a tripartite system of gods, even if all of the sacrificial information conveyed by Apollo could not be made to fit into that system perfectly. (In writing The Cave, Porphyry had more latitude in which to work than he did in The Philosophy, given that he was not quoting and interpreting Apollo: he could define his types of gods more or less as he wished and characterize their places of sacrifice selectively.) It is also important to note, on this topic, that Porphyry goes to some trouble to distinguish the epichthonioi from the bypochthonioi in the first lines of fr. 315 and then again later in the fragment: if Apollo's words compel him to group the epichthonioi with the chthonioi, he wants to ensure that the epichthonioi do not slip into another group with which the chthonioi are often joined - the gods of the Underworld. ${ }^{15}$

This analysis of fr. 314 and 315 from The Philosophy confirms what we may already have suspected: that Porphyry's more famous statement in The Cave reflects his own particular view of how space in the cosmos - and its gods can be categorized (even if he could have adduced evidence from popular beliefs, practices and oracles to support that particular view, as he did in The Philosophy). But the analysis has also helped to bring to the fore something that has gone unnoticed in all the modern discussions of the passage from The Cave: namely, that Porphyry seems to propose three divisions there, not the two that implicitly underpin modern attempts to dichotomize sacrificial procedures.

In fact, if we cite a bit more of The Cave than we customarily do when adducing it in discussions of sacrifice, we discover that the matter is even more complicated ( $\left.\int 6\right)$ :

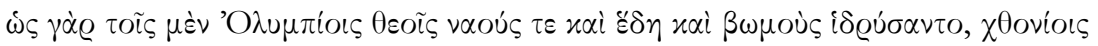

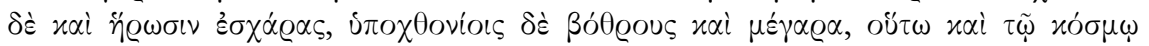

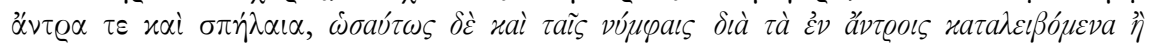

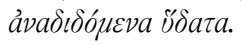

Just as they consecrated to the Olympian gods temples, shrines and altars; to the chthonioi and the heroes, sacrificial hearths; and to the bypochthonioi, ritual pits or trenches; so they dedicated caves and grottos to the cosmos; in the same way, too, they

${ }^{15}$ We do not know in what order Porphyry wrote his many works. Although scholars have tried to come up with a scheme based on his way his ideas about certain issues allegedly changed from work to work, TANASEANU-DÖBLER (2009) has persuasively shown that differences amongst the attitudes Porphyry displays in various places have more to do with differences amongst the genres in which he was writing than with genuine changes in his opinion - and she also shows that this was especially likely when Porphyry was writing about rituals. In short, it is fruitless to worry about whether the system of gods and sacrifices that he presents in The Cave chronologically precedes or follows the slightly different one we find in The Philosophy from Oracles. 
consecrated [caves and grottoes] to the nymphs because of the waters that flow either from above or below.

Just as the nymphs seem to comprise a category of their own in Apollo's words in fr. 314 of The Philosophy, so here as well Porphyry seems to suggest that they cannot be collapsed into any of the three groups he already has named. What I characterized shortly above as Porphyry's neoplatonic desire for tripartite tidiness seems to compete with his desire to explain and justify the significance of the passage from the Odyssey that he is treating (in which the nymphs play a prominent role), and at least partially gives way to it. We move even further away, then, from the neat dichotomy suggested by modern treatments than we were before.

This raises the question of why scholars have been so enamored of that dichotomy. As Renate Schlesier already showed ${ }^{16}$, the passages from classical authors that had been used to support it were weak; if Porphyry, who had been understood as one of the strongest pegs in the network of support, now looks unreliable as well, how can we explain the eagerness with which scholars developed and embraced a dichotomous approach to the gods and their worship?

When I first began to work on this question, I expected that the answer would have something to do with the Jewish and Christian background in which most western scholars of ancient religion had been raised, which similarly posits a strong dichotomy between types of superhuman powers. I hypothesized that earlier scholars would have expected, even if only unconsciously, to find a similar dichotomy of powers in Greek religion. As it turns out, however, I did not give earlier scholars enough credit. As Schlesier noted, although Creuzer and Müller helped to pioneer the thesis of an Olympian/ chthonian opposition, each also realized that 'a consistent dualism, a division of the world into two halves, a good and evil one, is not known [in ancient Greek religion].' Creuzer and Müller also recognized, moreover, that the Greek view both of what they called the Olympians and of what they called the chthonians was complex: each camp could be portrayed as the source of either good or evil. ${ }^{17}$ To whatever extent Creuzer, Müller and those who followed them assumed a dichotomy of gods, then, it was not imagined to be anchored in the dichotomy of Good vs. Bad that underlies traditional Jewish and Christian thought.

\footnotetext{
${ }^{16}$ SCHLESIER (1991/92), p. 44-47.

17 SCHLESIER (1991/92), p. 49-50, drawing especially on MÜLLER (1825) and CREUZER (18191823). The quotation is from MÜLLER (1825), p. 356 (I use SCHLESIER's translation).
} 
Perhaps the reasons for the origin of the dichotomizing theory cannot be definitively recovered. ${ }^{18}$ I would suggest, however, that its enduring popularity was guaranteed by one of the uses to which it was put in the late $19^{\text {th }}$ and early $20^{\text {th }}$ centuries by scholars such as Erwin Rohde and Jane Ellen Harrison namely, the investigation of some of the seemingly darker, and previously under-studied, aspects of Greek religion, including the cult of the dead and beliefs in ghosts and dangerous spirits such as Erinyes and keres - all of whom were classed by these scholars (even when not by the ancient sources) as 'chthonians.' ${ }^{19}$ What these scholars took as proof that the Greeks viewed the superhuman world as having been divided in half helped to justify their pursuit of what otherwise might have been perceived by some of their colleagues as an aberrant or at least unimportant course of study; naturally, therefore, they may have tended to exaggerate the differences between the two halves. The enormous influence of the so-called Cambridge Ritualists, amongst whom we must prominently place Harrison, would then have helped to further inculcate the dichotomy. Ironically, reaction to the Ritualists would have established it yet further: following the first World War, there was an insistent tendency among both scholars and the general public to portray the Greeks and their religion as rational and light-filled: the focus on chthonian elements that the Ritualists and others had embraced was displaced by an almost exclusive attention to what scholars continued to call, collectively, the Olympians. ${ }^{20}$ As I have discussed elsewhere, this trend by and large held good until the 1970s, when interest in the darker side of Greek religion once again began to grow. ${ }^{21}$ In other words, the perceived antithesis between Olympian and chthonian may have survived even thrived - as much because of the radical swings of fashion in scholarship from one side to the other as because of anything else. Walter Burkert reflects this in an interesting way, when he says: ${ }^{22}$

... the opposition between the Olympian and chthonic constitutes a polarity in which one pole cannot exist without the other and in which each pole only receives

18 SCHLESIER (1991/92), p. 39, proposes in passing that it springs in part from early 19thcentury Romantic interest in the Greeks, and especially their myths. This may well be correct.

19 I think especially of ROHDE (1925), Part I, and HARRISON (1922), chapter 1, although the dichotomy makes itself felt throughout Rohde's book and, to a great extent, throughout the rest of Harrison's scholarship. Most strikingly, in her last major work on Greek myth and religion (1924) HARRISON turns away from the chthonian topics that fascinated her earlier and decisively focuses on the Olympians, who, she claims, underpinned a religion that was a 'thing of glad confidence ... informed throughout by reason, a thing ... of sophrosyne, of sane thinking and feeling,' and a mythology that 'banished fear, fear which poisons and paralyzes man's life' (p. 144).

20 Indeed, even HARRISON herself seems to have turned in this direction, as the quotations from her 1924 book, offered in the immediately previous footnote, suggest.

21 JOHNSTON (2008b), p. 17-27, esp. p. 25-27.

22 BURKERT (1985), p. 202 and more generally p. 199-203. Burkert does, however, offer more nuanced statements elsewhere, as SCHLESIER (1991/92) points out on p. 48-49. 
it full meaning from the other. Above and below, heaven and earth form the universe. ... As there is no sunrise without a preceding night, so chthonic and Olympian ritual are constantly bound up with each other.

Burkert was moving towards recognition of the fact that two idealized categories could not be disentangled and isolated, but he insisted upon their existence nonetheless.

Let us return, in closing, to the texts with which this essay has been centrally concerned - Apollo's oracular words and Porphyry's interpretations of them and consider how our discussion may have better equipped us to think both about the ancient gods and their worship and about our own presumptions as we approach them. Porphyry's interpretations, which as I have shown strive towards a streamlined and sharply delineated structure, but which fall short of accomplishing it, should serve as a renewed caution against the scholarly desire to impose excessive order upon a religious system that is by its nature adaptable (as are most religious systems, wherever and whenever they have been practiced). And yet Apollo's words should caution us as well, for they suggest that the existence of transcendent categories (and of qualities by which those categories might be generally characterized) was not anathema to the Greek religious outlook: different modes or types of sacrifices were recognized to exist and to be appropriate for different gods. The very impossibility of pinning down Apollo's categories with complete precision speaks to the naturalness with which such categorization was taking place; whatever the 'real' source of the oracles we glimpse in fr. 314 and 315, they are not, in contrast to Porphyry, driven by a philosophical desire for ontological distinctions. Rather, the categories, such as they are, emerge organically from a discourse that is primarily aimed at guaranteeing that the gods receive what they require.

This should come as no surprise: the practices of religion frequently reflect and validate processes of categorization; categorization, and the acts of division on which it relies, whether they be implicit or explicit, are among the most common ways through which religion attempts to present the cosmos as having some reliable order, sufficient enough that humans can predict and cope with the challenges it presents. Although in recent decades we have rightly learned not to seek structures that will hold good in all cases, and have emphasized instead the polyvalence and flexibility of Greek religion, we must not ignore or explain away categorization when it does show up in our sources - the drive towards structure is central to religious experience.

We should be particularly sensitive to this when the guidelines for categorization are represented as having been conveyed through an oracle, because oracles are frequently concerned with establishing the proper ways in which relationships between humans and other entities are to be conducted (that is, with establishing and maintaining an at least reasonably orderly cosmos). Indeed, if we decide to look for something that approaches a system of Greek 
gods and their proper worship such as would have been widely accepted and understood, it is far likelier to be found in the words of an oracle than, for example, in the words of the tragedians or philosophers. Perhaps it is time to turn more attention to our fragments of Porphyry's On the Philosophy to be Derived from Oracles, and other recorded oracles, with this issue mind; perhaps we might begin to recover from such sources a better understanding of the innate distinctions that underlay ancient Greek religious thought and experience.

The Ohio State University

Sarah Iles JOHNSTON

Department of Greek and Latin

414 University Hall

230 N. Oval Mall

Columbus, OH 43210-1319

E-mail:jobnston.2@osu.edu

\section{Bibliography}

W. BurKeRT, Griechische Religion der archaischen und klassischen Epoche, Stuttgart, Kohlhammer, 1977 (trans. Greek Religion. Archaic and Classical, Oxford, Blackwell, 1985).

A. Busine, Paroles d'Apollon. Pratiques et traditions oraculaires dans l'antiquité tardive (II ${ }^{e}-V I^{e}$ siècles), Leiden/Boston, 2005.

G.F. CreuZER, Symbolik und Mythologie der alten Völker, besonders der Griechen I, IV3, Leipzig, 1819-

23 (repr. Hildesheim/New York, 1973).

S. EitREM, “Oraculum Apollonis a Porphyrio servatum,” SO 26 (1948) p. 176-177.

G. EkROTH, The Sacrificial Rituals of Greek Hero-Cults, Liège, 2002 (Kernos, suppl. 12).

—, "Pausanias and the Sacrificial Rituals of Greek Hero-Cults," in HÄGG (1999), p. 145-58.

A. FairbanKs, “The Chthonic Gods of Greek Religion,” AJPh 21 (1900), p. 241-259.

F. GrAF, "An Oracle Against Pestilence from a Western Anatolian Town," ZPE 92 (1992), p. 267-279.

R. HägG (ed.), Ancient Greek Hero Cult. Proceedings of the Fifth International Seminar on Ancient Greek Cult, organized by the Department of Classical Archaeology and Ancient History, Göteborg University, 21-23 April 1995, Stockholm, 1999 (ActaAth-8ㅇ, 16).

R. Hägg, B. Alroth (eds.), Greek Sacrificial Ritual, Olympian and Chthonian. Proceedings of the Sixth International Seminar on Ancient Greek Cult, organized by the Department of Classical Archaeology and Ancient History, Göteborg University, 25-27 April 1997, Stockholm, 2005 (ActaAth-8 ${ }^{\circ}$, 18).

J. HARrison, Mythology, Boston, 1924.

—, Prolegomena to the Study of Greek Religion, Cambridge, $1922^{3}$ (repr. New York, 1975).

A. Henrichs, "Sacrifice as to the Immortals. Modern Classifications of Animal Sacrifice and Ritual Distinctions," in HäGG - ALroTH (2005), p. 47-60.

S.I. Johnston, “Animating Statues: A Case Study in Ritual," Arethusa 41.3 (2008), p. 445-478 (= JOHNSTON 2008a).

—, Ancient Greek Divination, London, 2008 (= JOHNSTON 2008b). 
R. Merkelbach, J. Stauber, "Die Orakel des Apollon von Claros,” EA 27 (1996), p. 1-53 (= R. MerKelbaCh, Philologica. Ausgewäblte kleine Schriften, Stuttgart/Leipzig, 1997, p. 155218).

K.O. MÜLLER, Prolegomena zu einer wissenschaftlichen Mythologie, Göttingen, 1825.

A.D. Nock, “The Cult of Heroes," HThR 37 (1944), p. 141-174 (= Z. STEWART [ed.], Essays on Religion and the Ancient World, Oxford, 1972, p. 575-602.)

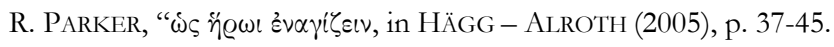

V. Pirenne-Delforge, Retour à la source. Pausanias et la religion grecque, Liège, 2008 (Kernos, suppl. 20).

E. RoHDE, Psyche. Seelencult und Unsterblichkeitsglaube der Griechen, 1890 (trans. Psyche. The Cult of Souls and Belief in Immortality among the Ancient Greeks, London, 1925).

J. RUDHARDT, Notions fondamentales de la pensée religieuse et actes constitutifs du culte dans la Grèce classique, Paris, $1992^{2}$ [1958].

R. SCHLESIER, “Olympian versus Chthonian Religion,” SCI 11 (1991/92) p. 38-51.

S. Scullion, "Sacrificial Norms, Greek and Semitic: Holocausts and Hides in a Sacred Law of Aixione," in P. BRulé (ed.), La norme en matière religieuse en Grèce ancienne, Liège, 2009 (Kernos, suppl. 21), p. 153-169.

—, "Saviors of the Father's Hearth: Olympian and chthonian in the Oresteia," in HÄGG - ALroTH (2005), p. 23-36.

—, "Olympian and Chthonian," CSCA 13 (1994) p. 75-119.

I. TANaseanu-DöBler, “,Nur der Weise ist Priester“: Rituale und Ritualkritik bei Porphyrios,” in U. Berner, I. Tanaseanu-Döbler (eds.), Religion und Kritike in der Antike, Münster, 2009, p. 109-155.

Z. VARHÉLYI, "Magic, Religion and Syncretism at the Oracle of Claros," in S.R. AsiRvathan, C.O. Pache, J. Watrous (eds.), Beyond Magic and Religion: Interdisciplinary Studies in Ancient Mediterranean Religion and Society, Lanham MD, 2001, p. 13-31.

G. WolfF (ed.), De philosophia ex oraculis haurienda, Berlin, 1856 (repr. Hildesheim/Zürich/New York, 1983). 